\title{
KEJSERKULT I DEN ROMERSKE HUSSTAND
}

\section{Af Ittai Gradel}

Romersk kejserkult har altid haft sin kristne eftertids bevågenhed, undren og forargelse. Fænomenet står stadigvæk i antikforskningen som et umage element, der nægter at lade sig indpasse $i$ vore vante begrebsmæssige båse: menneske contra gud, politik contra religion, rationalitet contra tro. P̊̊ vel intet område adskiller vores tankegang - præget som den er af jødisk-kristne begreber, der ofte opfattes som naturgivne og almene - sig mere fra den hedenske oldtids end på det religiøse, og intet fænomen illustrerer dette klarere end antikkens herskerkulter.

Ifølge forskningens generelle opfattelse hører kejserkult næppe hjemme inden for religionshistoriens område, for det stemples oftest som en politisk loyalitetstilkendegivelse snarere end et religiøst fænomen." Denne karakteristik synes mig noget letk $ø$ bt, dels i betragtning af vanskeligheden ved overhovedet at definere begrebet "religion «, dels fordi den ikke forklarer, hvorfor denne »politiske« loyalitet da formuleredes i et kultisk-religiøst formsprog.

Den »politiske« fortolkning af kejserkult finder dog tilsyneladende en vis støtte $i$ en anden almindeligt accepteret påstand, nemlig at kulten $i$ altovervejende grad var et offentligt (og dermed udvendigt og uoprigtigt) fænomen snarere end et privat. ${ }^{2}$ Skønt denne karakteristik ofte fremføres, er spørgsmålet dog kun sjældent blevet nærmere unders $\emptyset \mathrm{gt}$. Med udgangspunkt i Italien, det romerske kerneområde, vil jeg i denne artikel søge at indkredse, $\mathrm{i}$ hvor høj grad kulten vandt indpas $\mathrm{i}$ den enkelte husstand, det romerske samfunds basale sociale enhed.

Først vil det dog være på sin plads at give et kort rids af fænomenets udbredelse i den verden, der omgav det private hjem - dels i det enkelte italiske bysamfunds kultsystem, dels i private kultsammenslutninger uden for husstanden.

\section{Kejserkult uden for husstanden ${ }^{3}$}

Fra og med Augustus fandtes i hele det romerske imperium kulter (dvs. ofringsceremonier) viet den regerende kejser. Italien - inklusive Rom - 


\section{Kejserkult i den romerske husstand}

udgjorde dog efter forskningens almindelige opfattelse en undtagelse. Dette synspunkt støtter sig på Cassius Dio $(51,20,8)$ fra o. 200 e.v.t., der beretter, at ingen kejser vovede at tillade egentlig guddomskult . dvs. ofringer, templer og altre - til sig selv i Rom og det øvrige Italien. Her kunne kejseren først opnå guddomsstatus efter sin død, hvis han af det romerske senat blev deificeret (med tilnavnet Divus) og dermed optoges i romerstatens gudepantheon.

Så længe de ikke vovede sig ud i forbrydelser mod staten eller kejseren (crimen maiestatis), kunne privatpersoner dyrke hvem og hvad de ville uden indblanding - eller interesse - fra statsmagtens side. Cassius Dios karakteristik dækker således kun de offentlige kulter: Roms statskult og de italiske bysamfunds kulter. Hvad angår de private kulter, bevidner indskriftmaterialet utvetydigt, at den regerende kejser dyrkedes som gud i hele Italien inklusive Rom, hvorfra der kendes både templer og altre til kejseren, opsat af private kultsammenslutninger. ${ }^{4}$ Det traditionelle forskningssynspunkt er således under alle omstændigheder forkert.

Vender vi os mod Italiens offentlige kulter, er billedet mere nuanceret. I statskulten, Roms bykult, er det utvivlsomt korrekt, at der - med få, kortvarige undtagelser, primært Caligula (37-41 e.v.t.) - ikke fandtes kult af den regerende kejser, kun af Divi. Dette skyldtes, at statskulten udgjorde en del af Roms »forfatning«, og statskult af et menneske var i romerske øjne ensbetydende med en monarkisk statsform. Da det romerske kejserdømme, som det etableredes under Augustus, netop ikke - formelt - var et monarki, var guddomskult af Augustus i levende live en konstitutionel umulighed. ${ }^{5}$ Efterhånden udvikledes Rom til mere og mere også formelt at være et monarki, men da havde præcedens antaget sit eget liv: Eftersom kejseren kun kunne indlemmes i Roms gudepantheon efter sin $d ø d$, kom forslag om statslig gudestatus i levende live til at udtrykke et usmageligt varsel eller $\emptyset$ nske om majestætens snarlige bortgang. ${ }^{6}$ Fra 0.50 e.v.t. dyrkedes imidlertid den regerende kejsers Genius (»livskraft«) i statskulten. ${ }^{7}$ Baggrunden herfor var den romerske huskult: Fra gammel tid dyrkede husherrens - paterfamilias - slaver, frigivne og familie hans Genius og hans Larer (husguder) i den enkelte husstand. ${ }^{8}$ De formulerede herved i kultisk formsprog deres underkastelse under husherrens totale myndighed. Da alle mænd havde en Genius - uanset om den var genstand for kult eller ej - lå der i denne 
dyrkelse intet krav på guddommelighed, ud over hvad alle mænd besad.

I Roms statskult fandtes således ingen direkte kult af den regerende kejser. Så langt har Cassius Dio ret. Det synes imidlertid ikke at være tilfældet, hvad angår de offentlige kulter i Italiens byer uden for hovedstaden. Gældende teori siger, at kun kejserens Genius, ikke kejseren selv dyrkedes i disse kulter. Denne tolkning, der forsøger at forlige Cassius Dios udsagn med det tilsyneladende modstridende arkæologiske og epigrafiske materiale fra Italien, fremsattes af L. R. Taylor i 1920.9 Ingen af de indskrifter - betegnelser på templer, tempel- og alterdedikationer, præstetitler - der bevidner bykulter til kejseren, nævner imidlertid hans Genius. Tværtimod fremstår kulterne undtagelsesløst som viet kejseren selv, ganske som i kulter af de gamle, »rigtige« guder.

Sikkert er det derimod, at kejserens Genius dyrkedes i de såkaldte Compital-kulter. I 7 f.v.t. gennemførte Augustus en administrativ nyordning af Rom, hvor hovedstaden opdeltes i 14 regioner og 265 vici (bykvarterer). I republikken havde hver vicus fra gammel tid i Compitalkulterne dyrket sine skytsguder, sine vejkryds-Larer (Lares compitales, Larer der dyrkedes ved korsveje - compitum: korsvej). Kulterne blev i senrepublikken centre for politisk uro, og de undertryktes derfor. I forbindelse med Augustus' administrative nyordning af hovedstaden genoprettedes kulterne, én i hver vicus, men med en væsentlig innovation: I den nye kultform dyrkedes foruden Larerne også kejserens Genius, og kultens Larer var fra da af Augustus' egne hus-Larer, for de benævntes herefter ikke Lares compitales som i republikken, men konsekvent Lares augusti. Compital-kulterne blev således »aflæggere a af Augustus' egen huskult. ${ }^{10}$ Den nye kult fandt hurtigt vid udbredelse over hele Italien.

Der var således - vidt udbredt - kejserkult i Italien i tidlig kejsertid, i hvert fald i byerne. Dér kunne de fleste af Italiens indbyggere næppe undgå at blive konfronteret med kultisk dyrkelse af deres kejser. Tiden er nu inde til et forsøg på at indkredse, i hvor høj grad dette afstedkom en respons på »hjemmefronten«.

\section{Kejserkult inden for husstanden}

Det arkæologiske materiale har så godt som aldrig leveret vidnesbyrd om kejserkult inden for det enkelte romerske domus. Mosaikker og vægmalerier fra privathuse i Pompeii, Ostia og andre lokaliteter har 


\section{Kejserkult i den romerske husstand}

ikke afsløret referencer til kejserkulten. Dette er understreget af $\mathrm{E}$. Bickerman, der også fandt fraværet af kejserlige portrætter i privat kontekst slående."

Kan denne iagttagelse bruges til at konkludere, at kejserkulten - og kejserlige æresbevisninger i det hele taget - kun spillede en rolle i det offentlige liv og ikke havde betydning eller fandt accept hos det enkelte individ, som Bickerman antydede? ${ }^{12}$

Man kunne med rimelighed spørge, hvorfor kejseren, hvis område var den offentlige velfærd, skulle påtræffes i privat kontekst? ${ }^{13}$ Først må det imidlertid være på sin plads at undersøge, om Bickermans påstand er korrekt, og på hvilke præmisser den hviler.

De foreliggende vidnesbyrd bekræfter faktisk ikke dette påståede fravær. Som generelt for private kejserkulter var det også i privathuset den regerende kejser, der var i fokus fremfor Divi. Denne påstand bekræftes, mener jeg, af det tilgængelige materiale, som jeg om lidt vil gennemgå. Hvis fokus i husstanden således var på den regerende kejser, vil det være absurd at vente f.eks. mosaikker eller vægmalerier med afbildninger af kejseren; portrætterne og kultens materielle indslag må da have været af mere temporær karakter. Her er vi efter min opfattelse ved sagens kerne, for der er ikke i denne sammenhæng tidligere gjort opmærksom på et tilsyneladende indlysende faktum, nemlig at de monumenttyper, der efterlader sig de tydeligste arkæologiske spor, netop er de mere stationære, ikke temporæere, typer som f.eks. mosaikker og vægmalerier. ${ }^{14}$ Disse mere stationære monumenttyper var også de $\emptyset$ konomisk mest krævende at opsætte, hvorfor deres motiver - primært fantasiarkitektoniske og mytologiske skilderier - havde en mere »tidløs« og generel appel. Som begrundelse for sin undren over det næunte fravær peger Bickerman på moderne paralleller: "Think of the portraits of Stalin, of Hitler, and even of Nasser, in every shop, in every home of their respective subjects« (s. 5). Men af disse portrætter i de tusind hjem, papirreproduktioner af fotografier eller malerier, eller sjældnere løse småbuster, ville der jo netop ikke være ringeste identificerbare spor ved en langt senere udgravning. Da den romerske kejser hvert øjeblik kunne gå bort, er det logisk, at eventuelle portrætter i privathuse ligeledes for vor periodes vedkommende må have været af temporær karakter, da en større, bekostelig vægudsmykning eller gulvmosaik hvert $\emptyset j e b l i k$ kunne miste sin relevans. 
Kejserens påståede fravær i den romerske husstand hviler således delvis på en metodisk fejlslutning. F.eks. vil ophængte panelmalerier i Pompeii ikke være sporbare i en udgravning, ${ }^{15}$ hvad angår statuetter af husguderne, hvor man kunne tænke sig kejserportrættet inkluderet, er det imidlertid korrekt, at der fra Pompeii ikke er eksempler herpå. Det er umuligt at sige, $\mathrm{i}$ hvor høj grad de kejserlige miniatureportrætter, der er os overleveret, ${ }^{16}$ er indgået i en sådan kultisk sammenhæng, eller om de blot har fungeret som udsmykning. Begge dele har ifølge de skriftlige kilder været udbredt; hvad angår i hvert fald sidstnævnte funktion, nævner Fronto (o. 150 e.v.t.), at portrætter, malede eller skulpterede, af Marcus Aurelius kunne ses i alle butikker, vinduer, taberner, ja overalt i Rom. ${ }^{17} \mathrm{Vi}$ må dog ikke glemme, at de skriftlige kilder generelt kun beskriver byromerske forhold.

Det er rigtigt, at kun få kejserlige portrætter er fundet i privat kontekst. Men hvis man betæenker, hvor få af de bevarede portrætter, der overhovedet er behæftet med en identificerbar fundkontekst, falder også dette argument til jorden. Der er faktisk flere eksempler fra Italien og andetsteds på en sådan fundkontekst. ${ }^{18}$ En portrætstatue af Livia fandtes således i Mysterievillaen i Pompeii; ${ }^{19}$ en samling kejserlige julisk-claudiske portrætter blev i 1880 fundet i fundamentet til en tilsyneladende samtidig villa $\mathrm{i}$ Rom; ${ }^{20}$ en lille buste af Commodus fandtes i en caupona i Ostia. ${ }^{21}$ Også i de litterære kilder er der eksempler. Plinius d.y. besad på et af sine godser en statuesamling af afdøde kejsere, som han havde arvet; han søgte kejser Nerva om tilladelse til at føje dennes statue til samlingen og overføre den til Tifernum, hvor han ville bygge et tempel til portrætterne og overdrage det til byen, hvis patron han var. Ans $\emptyset$ gningen blev senere gentaget over for Trajan; i begge tilfælde blev tilladelsen givet, og templet blev bygget. ${ }^{22}$ Ovid besad - og dyrkede - i sit eksil i Tomi sølvbilleder af Augustus, Tiberius og Livia. ${ }^{23}$ Hans situation var speciel; men Tacitus nævner i forbindelse med en sag under Lex Maiestatis i Tiberius' første regeringsår en Augustus-statue i en privatmands haver, og af Tiberius' kendelse i denne forbindelse om statuer af forgængeren fremgår, at de også fandtes i private huse. ${ }^{24}$

I samme passage giver Tacitus os den nok mest oplysende omtale overhovedet af kejserkult i det romerske domus, da han en passant næevner "Augustus' dyrkere, der fandtes $i$ alle husstande « $i$ sen augustæ-isk tid. Skønt Tacitus muligvis overdriver, og skønt oplysningen måske 


\section{Kejserkult i den romerske husstand}

kun er relevant for byen Rom (som de litterære kilders udsagn generelt), er der næppe grund til basalt at drage hans ord i tvivl. ${ }_{0}^{25}$

Hvad Pompeii angår, er der generelt - også i offentlig kontekst - kun fundet ganske få kejserlige portrætter. Kejserlige miniature-portrætter er ikke fundet $\mathrm{i}$ byens mange bevarede lararier (hus-helligdomme), hvor statuetter af husguderne stod placeret. I 26 tilfælde er disse statuetter fundet in situ. ${ }^{26}$

Der er flere litterære belæg for den praksis at opstille billeder af kejseren eller andre velgørere $\mathrm{i}$ larariet blandt de andre husguder. ${ }^{27}$ Hofsnogen L. Vitellius, fader til den senere kejser, dyrkede således forgyldte billeder af Claudius' frigivne Narcissus og Pallas mellem sine Larer, ${ }^{28}$ og M. Aurelius ærede sine lærere i en sådan grad, at han ligeledes indsatte deres forgyldte billeder i sit lararium. ${ }^{29}$ Sueton forærede et bronzebillede af Augustus som barn til Hadrian, som dyrkede det mellem Larerne i sit soveværelse. ${ }^{30}$ Ifølge Historia Augusta, M. Antoninus 18,6 var Marcus Aurelius' popularitet så stor, at det ansås for helligbrøde ikke at have hans billede i sit hus, hvis man var i stand til det, og selv i forfatterens tid fandtes hans statue blandt husguderne i mange hjem. $^{31}$

De her fremlagte passager har én ting til fælles: de nævnte tilfælde omtales, fordi de er undtagelser fra det normale mønster og derfor får interesse. Vitellius' dyrkelse af de kejserlige frigivne nævnes som eksempel på hans servile adulatio og sleskhed. At en højtstående senator, konsul tre gange og censor med Claudius, skulle dyrke eks-slaver, og dermed socialt underkaste sig dem, har syntes en uhyrlig og latterlig selvydmygelse i romerske øjne, og det er dette groteske aspekt, der forlener eksemplet med interesse og gør, at det nævnes. Netop fordi Vitellius har haft billeder af de kejserlige eks-slaver i sit lararium, har han utvivlsomt også haft et af Claudius i det; men heri lå intet usædvanligt, for, sk $\emptyset$ nt højtstående, befandt Vitellius sig socialt langt under kejseren. Derfor var den sociale underkastelse i dette tilfælde naturlig, og derfor nævnte Sueton det ikke, for hvilken interesse kunne det have haft? Det samme gælder anekdoten om Marcus og hans lærere, der skal illustrere hans affektion for dem, en affektion så stor, at han dyrkede personer, der socialt stod så dybt under ham selv. ${ }^{32}$ Hadrians dyrkelse af det lille Augustus-billede nævnes naturligvis af Sueton i stolthed over, at kejseren ærede hans gave så højt. Beretningerne i Historia Augusta om 
Marcus Aurelius' portrætter i privathuse fremføres tydeligvis, fordi det var usæedvanligt, at det ligefrem regnedes for helligbrøde ikke at have kejserbilledet i sit hus, hvis det var én økonomisk muligt, samt - hvis ikke dette er for dristig en slutning, kildens upålidelighed taget i betragtning - fordi det var usædvanligt at have portrætter af en kejser i larariet længe efter dennes død.

Skønt det stod enhver frit, hvem og hvad han ville dyrke blandt sine husguder, finder jeg det ikke for dristigt at postulere, at fokus i denne form for kult har været rettet mod den regerende kejser. For det første gælder dette uniformt for private kultsammenslutninger; ${ }^{33}$ for det andet var libationen før private banketter, et emne jeg vil behandle om lidt, kun viet den regerende kejser; for det tredie er det vanskeligt at se, hvorfor opmærksomheden skulle være rettet kronologisk bagud, fremfor at koncentrere sig om den kejser, af hvem den samtidige velfærd og rigdom først og fremmest afhang. ${ }^{34}$

De få samlede fundkontekster af husguds-statuetter fra Pompeii inkluderer ikke i noget tilfælde kejserbilleder; dette tillader os højst at slutte, at praksis med at indsætte kejseren blandt husguderne ikke har været almindeligt udbredt, hvad der som nævnt også bekræftes af passagen i Historia Augusta. De skriftlige kilder under ét synes imidlertid at vise en betydelig udbredelse af fænomenet, for de eksempler, vi møder deri, er som sagt alle på den ene eller den anden vis undtagelser. Det generelle og almindelige tilfælde nævnes ikke, hvad der dårligt kan forklares på anden vis, end at det har været almindeligt kendt og derfor uden interesse. Af samme grund er den romerske husstandskult som sådan dårligt belyst af de skriftlige kilder.

Det er i høj grad muligt - siden disse kilder jo koncentrerer sig næsten ganske om hovedstaden - at vi her har at gøre med et overvejende byromersk fanomen; den betydelige geografiske udbredelse af private kejserkult-sammenslutninger uden for husstanden tyder imidlertid ikke på ligegyldighed eller manglende entusiasme uden for Rom og de højeste socialklasser dér.

Også på et andet område kom kejserkulten ind i det romerske domus, her ikke uformelt og på individuelt initiativ, men ved et senatsdekret. I 30 f.v.t. besluttede Senatet, at der skulle udhældes en libation til Octavian ved alle banketter, private såvel som offentlige (Cassius Dio $51,19,7)$. Denne rite nævnes flere steder i de skriftlige kilder, således 
af Horats $^{35}$ og Ovid. ${ }^{36}$ Af begge disse kilder fremgår det, som også af den vigtigste, Petronius, at kejseren æeredes på denne vis i forbindelse med husets Larer. Af hverken Horats eller Ovid kan sluttes, at skikken har været generelt udbredt. Horats' ode er henvendt til Augustus selv, og omtalen af ritualet kan i begge tilfælde forklares som smiger af princeps fra poeternes side. Langt mere oplysende i så henseende er Petronius (60), hvor der ved Trimalchios middag mellem cena og secunda mensa, bragtes nogle safran-udspyende kager og frugter ind på bordet. Gæsterne troede, at det måtte være en guddommelig æresbevisning, ${ }^{37}$ og de rejste sig alle og råbte "Augusto patri patriae feliciter ${ }^{38}$. Derefter trådte tre slaver ind $i$ rummet, og to af dem anbragte statuetter af Larerne (sc. Trimalchios) på bordet, mens den tredie gik rundt med en patera fuld af vin og råbte »dii propitii .

I denne tekst kan det udelukkes, at ritualet beskrives for at smigre kejseren, ${ }^{39}$ og middagsgæsternes helt automatiske reaktion viser, at ceremonien må have været generelt udbredt; det fremgår faktisk ikke af teksten, om de duftende madvarer virkelig var ment som en hyldest til kejseren, eller om de blot opfattedes sådan af gasterne. Det bør bemærkes, at i ingen af de tekster, hvor denne libation omtales, indgår der et billede af kejseren i kulthandlingen; dette fænomen ville i så tilfælde end ikke teoretisk kunne afsætte sig spor i det arkæologiske materiale, endnu en advarsel mod at slutte for meget ud fra fravaret af kejserlige referencer i privathuse.

L. R. Taylor påstod i 1931 - uden diskussion, men som et selvfølgeligt faktum - at libationen var til kejserens Genius, ${ }^{40}$ og denne fortolkning er accepteret af alle senere forfattere. ${ }^{41}$ Taylor nævner endda libationen som et sikkert eksempel, hvor Genius er undertrykt/underforstået, men ikke nævnes ved kulthandlingen, til støtte for, at det samme skulle være tilfældet ved det såkaldte Vespasian-tempels kult i Pompeii og derfra generelt for kejserkulten i Italien. ${ }^{42}$ Det er imidlertid ikke påpeget før, at alle de relevante kilder til dette fænomen nævner kejseren selv, ikke hans Genius, der overhovedet ikke optræder i denne forbindelse. Hele Taylors argument er derfor en cirkelslutning.

Der er dog én mulig støtte for, at libationen var til kejserens Genius. I haven til et privathus i Pompeii (IX, IX, 13) findes på vestmuren nær sydhjørnet en lille niche (lararium), til højre for hvilken tidligere forfattere har beskrevet et maleri, ${ }^{43}$ hvoraf så godt som intet nu er 


\section{Ittai Gradel}

bevaret. ${ }^{44} \mathrm{Jeg}$ overlader her ordet til Boyce, der beskriver scenen, tilsyneladende efter selvsyn:

On the 1. stands a tripod of unusual form, with a dark-colored vessel upon it. The Genius, standing to the $\mathrm{r}_{\text {, }}$, pours a libation upon the tripod; he wears a wreath of leaves; the toga does not seem to be drawn over his head as usual, though the preservation of the painting is poor at this point; he holds no cornucopia. Behind and to the r. stand two figures: in the first plane, a camillus; also wreathed, and carrying fruit in a shallow dish; above and farther r., a popa, wreathed and carrying an ax. To the 1. of the Genius are two wreathed figures, apparently women, though it is impossible to be certain, for only the upper portions of their figures are preserved. On the 1. side of the niche there was not room for painted figures, but on the adjoining $\mathrm{S}$. wall the figure of the Genius appears again, clad in white toga and pouring a libation upon a yellow cylindrical altar with a fire; he is unbearded, his flesh is reddish, in his 1 , he holds a yellow cornucopia.

Genius på sydmuren fortolkedes af Mau som Genius Augusti, optaget i huskulten $\mathrm{i}$ henhold til det af Cassius Dio omtalte senatsdekret; for under denne Genius var omhyggeligt indridset en graffito med $9 \mathrm{~cm}$ høje bogstaver: EX S[enatus] C[onsulto] (»Efter senatsdekret«). ${ }^{45}$ Denne Genius var ikke samtidig med resten af maleriet, men blev bevidst bevaret ved omdekoreringen af væggen, til hvilken fase den øvrige fremstilling hørte.

Denne attraktive, men dristige fortolkning er accepteret af alle senere forfattere. Der er imidlertid efter min opfattelse vagtige indvendinger. Hvis Maus tolkning er rigtig, er Genius som libationsmodtager her i modstrid med hele det øvrige materiale, gennemgået ovenfor, hvor libationen var til kejseren selv. Desuden er der intet ved den anden „Genius« (på vestvæggen), der identificerer figuren som en sådan: Den havde tilsyneladende hverken togaen trukket op over hovedet, eller cornucopia. Rimeligere er det derfor at opfatte figuren som præst i den på vestvæggen afbildede offerscene, og der er således kun en enkelt Genius afbildet - som normalt i de pompejanske larariemalerier ${ }^{46}$ nemlig sydvæggens figur.

Hvis vi nu accepterer, at denne figur er Genius Augusti, synes det mig rimeligere at se denne kult af kejserens Genius i lyset af Compitalkulten. Husets ejer kan have været en magister vici, der i sin egen have har indrettet en privatkult af Genius Augusti, som han havde dyrket i sit embede. ${ }^{47}$ Indskriften EX S.C. refererede da til det senatsdekret, der beordrede reorganiseringen af Compitalkulten og optagelsen af Genius 


\section{Kejserkult i den romerske husstand}

Augusti heri i 7 f.v.t. ${ }^{48}$ Min tolkning er dristig, men ikke mere end Maus, og modstriden med de litterære kilder vil dermed være opklaret, for maleriet har intet med kejserlibationen at gøre.

Også den afbildede kultscene på vestvæggen er afvigende $\mathrm{i}$ forhold til de øvrige pompejanske larariemalerier med offerscener. I disse er husherrens Genius og/eller hans Larer altid afbildet, altså de guder til hvem offeret foretages. Det gælder ikke her - den såkaldte Genius var som nævnt præst i ceremonien, og af Larerne var der intet spor. Det synes derfor rimeligst at opfatte kulthandlingen som viet den eneste gud, der er afbildet, nemlig Genius Augusti på sydvæggen. ${ }^{49}$ Hvis dette er korrekt, er Maus tolkning umulig. Offertjeneren (popa) med øksen i kultscenen viser nemlig utvetydigt - skønt et offerdyr ikke var afbildet at et blodoffer har indgået i ceremonien, mens libationen til kejseren i sagens natur var et ublodigt offer. Selv hvis dette blodoffer har været til andre guder, såsom Larerne, er en sammenhæng mellem præstens libation og Genius Augusti næppe mulig. For kilderne nævner enstemmigt, at den kejserlige libation skulle udgydes, og blev udgydt, umiddelbart før måltidet, eller ifølge Petronius mellem to retter i måltidet. På maleriet fandt libationen imidlertid sted før slagtningen, ${ }^{50}$ eller i hvert fald kronologisk samhørigt dermed, som popa med øksen viser. Maus tolkning kan da kun accepteres, hvis Genius Augusti og kultscenen ikke havde forbindelse med hinanden.

Maleriets talrige anomalier forklares da bedst med, at det ikke er et larariemaleri, men at det afbilder en privat domuskult af Genius Augusti, der fandt sted i denne have. Funktionen af huset, hvortil haven hører, er uklar og kan derfor ikke hjælpe os i diskussionen. ${ }^{51}$ Under alle omstændigheder er Maus tolkning så usikker, at den ikke kan have vægt sammenholdt med de litterære kilder, hvis tale er klar: Libationen, der dekreteredes af Senatet i 30 f.v.t., var til Octavian selv - ikke til hans Genius.

Med denne gennemgang håber jeg at have sået tvivl om et gennemgående dogme i kejserkult-forskningen: At fænomenet primært var offentligt. Kildematerialets beskaffenhed medfører automatisk, at vi er mere velorienterede om de offentlige kulter, netop fordi de var offentlige, og dermed i højere grad publiceredes (væsentligst i monumentalindskrifter). Alene dette faktum bør medføre skepsis over for bemeldte påstand. Og dog bevidner de langt dårligere kilder til husstandskulten en 
vis udbredelse også i denne sfære. Faktisk hviler teorien om det offentlige aspekts større betydning p̊̊ en $\mathrm{i}$ orienteringen indbygget præmis, idet de private kejserkulter - herunder husstandskulterne - er blevet næsten ganske overset af forskningen, mens så godt som al opmærksomhed har været koncentreret på de mere spektakulære offentlige kulter.

Kejserkultens vide udbredelse $\mathrm{i}$ såvel den offentlige som den private sfære kan ikke bortforklares ved at stemple den som politisk, udvendig eller hyklerisk: Dyrkerne mente det alvorligt. En jødisk-kristent tænkende eftertid - herunder vi - kan finde dette absurd eller endog blasfemisk. Det er imidlertid en anden historie.

\section{Noter}

1. Forestillingerne om hykleri og kulten som et politisk snarere end et religiøst fænomen er nært sammenknyttede og afhænger af hinanden. Se f.eks. J. H. W. G. Liebeschuetz, Continuity and Change in Roman Religion, 1979, 78, der forsøger et kompromis: "... fundamentally a secular institution, but this would not prevent men who believed in survival of the empire from being sincerely and emotionally involved in it (det samme kunne efter min opfattelse siges med lige så stor ret om hele den romerske statskult); A. D. Nock i Cambridge Ancient History X, 1934, 481 ff.: »... of the nature of homage and not of worship in the full sense - men han erkendte, at distinktionen nappe fandtes $\mathrm{i}$ antikken (Essays on Religion and the Ancient World, 1972, 241); K. Latte, Römische Religionsgeschichte, 1960, 312 ff. (»Loyalitätsreligion«). Se S. Price, Rituals and Power, 1984, for et opgør med denne indgroede forestilling.

2. Liebeschuetz 1979, 75: "... must have involved an apalling amount of hypocrisy«; G. W. Bowersock, "Greek Intellectuals«, i den Boer (ed.) 1973 (se n. 11), 206: »No thinking man ever believed in the divinity of a living emperor «. For opgør med disse forestillinger, se Price 1984, 114 ff.; han accepterer dog - uden begrundelse - at »the imperial cult operated primarily in the public gaze«. Price tager her ikke hensyn til den større økonomiske formån bag offentlige kulter, der derfor, alt andet lige, vil have efterladt flere arkæologiske (herunder epigrafiske) vidnesbyrd end private kulter.

3. De i dette afsnit berørte aspekter har jeg behandlet mere udførligt andetsteds: »Var der kejserkult i Rom og Italien?«, Den Jyske Historiker, forår 1990 (temanummer om Antikken, under udgivelse).

4. F.eks. Corpus Inscriptionum Latinarum (CIL) VI, 218 (kultbilleder, tempel og alter til Septimius Severus og Caracalla), 927 (tempel til Nero og guden Silvanus), 961 (alter til Trajan). For oversigt over de af kejserkultsammenslutningerne, der benævntes cultores, se E. de Ruggiero, Dizionario Epigrafico, 1895 ff., s.v. cultores; for nærmere behandling, se min prisopgave "Kejserkulten i Rom og Italien«, Aarhus Universitet, Det humanistiske Fakultet 1988.

5. Cæesar var derimod blevet deificeret af Senatet kort før sin død; se S. Weinstock, Divus Julius, 1970, for kilderne.

6. Jf. Tacitus, Annales 15, 74.

7. Tidligst bevidnet 55 e.v.t. i Arval-brødrenes akter (CIL VI, $32352=$ A. Pasoli, Acta Fratrum Arvalium, 1950, 115). 


\section{Kejserkult i den romerske husstand}

8. For huskulten generelt, se D. G. Orr, »Roman Domestic Religion: The Evidence of the Household Shrines«, Aufstieg und Niedergang der römischen Welt. Geschichte und Kultur Roms im Spiegel der neueren Forschung II, 16,2, Berlin 1978, $1557 \mathrm{ff}$.

9. Transactions and Proceedings of the American Philological Association 51, 1920, 128 ff.; L. R. Taylor, The Divinity of the Roman Emperor, 1931, $216 \mathrm{ff}$.

10. Compitalkulten tilhørte et mellemstadium mellem offentlig og privat kult, der i romersk sakralretslig terminologi benæevntes popularia sacra (Pauly-Wissova, Realleksikon der classischen Altertumswissenschaften (RE) s.v. Sacra).

11. E. Bickerman, »Consecratio , i W. den Boer (ed.), Le culte des souverains dans l'empire romain, (Entretiens Hardt XIX), 1973, 3 ff.

12. Smst. 5: "On the other hand, we may ask and should ask whether and how far the imperial worship was accepted and favored by the common man«. Jf. Hopkins, Conquerors and Slaves, 1978, 220, note 33.

13. Som Millar bemærkede i Bickerman 1973, 29 ff.

14. Helt bortset fra, at privathuses vægmalerier - bortset fra larariebillederne - og mosaikker så godt som aldrig gengiver kultscener eller kultbilleder.

15. For panelmaleri af Trajan i et privat sovekammer hundrede år efter kejserens død, se Historia Augusta, Alexander Severus 13,2.

16. Se B. Schneider, Studien zu den kleinformatigen Kaiserporträts von den Anfängen der Kaiserzeit bis ins dritte Jahrhundert, 1976. To miniatureportratter af Augustus stammer fra Herculanum, men de nærmere fundomstændigheder er ukendte ( $7 \mathrm{ff}$.).

17. Epistulae ad M. Caesarem 4, 12,6 (Loeb, 1. ed., 207; ed. van den Hout, 1954, 67): »Scis ut in omnibus argentariis mensulis perguleis taberneis protecteis vestibulis fenestris usquequaque ubique imagines vestrae sint volgo propositae, male illae quidem pictae pleraeque et crassa, lutea immo, Minerva fictae scalptaeve ...«.

18. Jeg følger her Price 1984, 119, der som den første har påpeget dette. Jf. desuden $R$. Neudecker, Die Skulpturenausstattung römischer Villen in Italien, 1988; de heri anførte eksempler kan dog stamme fra kejserlige villaer og vil i så fald naturligvis vare irrelevante. For private fundkontekster uden for Italien se det lige næevnte sted hos Price og tilføj Bickerman 1973, 6.

19. A. Maiuri, La Villa dei Misteri, 1931, 223 ff.

20. D. K. Hill, $» A$ cache of bronze portraits of the Julio-Claudians«, American Joumal of Archaeology 43, 1939, 401 ff.; kun Augustus og, efter min opfattelse, Nero kan med rimelig sikkerhed identificeres. Villaens mure var i opus reticulatum. (Notizie degli scavi di antichità (NSc) 1880, 466), dateringsmæssigt kongruent med portrætterne; men grundet de dårligt belyste fundomstændigheder kan intet yderligere siges med sikkerhed.

21. NSc 1916, 417 ff.; fem huller i bustens hår indicerer en corona radiata ( $R$. Calza og M. F. Squarciapino, Museo Ostiense, 1962, 52).

22. Plinius, Epistulae 10,8; 3,4; 4,1. Et interessant tilsvarende eksempel giver CIL XIV, 2795 (Gabii, dat. 140 e.v.t.): et tempel bygget in honorem memoriae domus Domitiae Augustae af to af hendes frigivne skænkedes af dem til Gabii (sammen med en pengegave), og kulten, hvori indgik fejring af den afdøde kejserindes fødselsdag, blev dermed offentlig; $i$ betragtning af Domitia Longinas status som »ikke-person« efter Domitians $\mathrm{d} \emptyset \mathrm{d}$ (hendes eksistens forties ganske i de skriftlige kilder), er indskriften besynderlig. Men da der ikke kendes tilsvarende offentlige kulter fra Italien af privatfolk og deres domus, må fænomenet forklares med hendes kejserlige rang. For Domitia Longina samt indskriften se W. C. McDermott and A. E. Orentzel, Roman Portraits. The Flavian-Trajanic Period, 1979, $69 \mathrm{ff}$. 


\section{Ittai Gradel}

23. Ovid, Ex Ponto 2,8; 4,9,105 ff.

24. Tacitus, Annales 1,73: $\gg N e c$ contra religiones fieri, quod effigies eius [sc. Augusti], ut alia numinum simulacra, venditionibus hortorum et domuum accedant $\ll$. Jf. smst. 4,64 (portræt af Tiberius i senators hus). Portrætter af Augustus i privathuse, opsat mens han levede, må have varet særdeles hyppige, når betænkes cultores Augusti, der nævnes af Tacitus tidligere i samme passage (se nedenfor). I betragtning af, hvor få indblik overhovedet den romerske kejsertidslitteratur giver os $\mathrm{i}$ det enkelte domus, kan dens få referencer til kejserportrætter i denne kontekst ikke bruges til at postulere deres generelle fravær.

25. »... cultores Augusti, qui per omnes domos in modum collegiorum habebantur ...«. Konteksten er de første majestætsforbrydelses-processer under kejser Tiberius, hvor Tacitus polemiserer mod denne kejser, ikke mod Augustus (der tværtimod sættes i positiv kontrast til »udyret« Tiberius). Da oplysningen om cultores Augusti således ikke tjener noget polemisk formål, kan den med rimelighed betragtes som faktuel.

26. G. K. Boyce, "Corpus of the Lararia of Pompeii «, Memoirs of the American Academy in Rome 14 (1937), reg. s.v. Statuettes.

27. Da husherrens Genius stod i den enkelte husstands lararium, var budskabet ved at indsætte billedet af velgøreren, evt. hans Genius, at man gav sig ind under hans manus, lod sig optage i hans husstand.

28. Sueton, Vitellius 2,5: "Narcissi quoque et Pallantis imagines aureas inter lares coluit«.

29. Historia Augusta, M. Antoninus 3,5: »tantum honoris magistris suis detulit ut imagines eorum aureas in larario haberet«. Alexander Severus havde ifølge samme kilde (Alexander Severus 29,2) i sit lararium billeder af Apollonius af Tyana, Kristus, Abraham og Orpheus; det nævnte Kristus-billede vækker dog mistænksomhed mod den langt senere og ofte upålidelige kilde.

30. Sueton, Divus Augustus 7,1: »... imagunculam ..., quae dono a me principi data inter cubiculi lares colitur «.

31. Den sidste oplysning er specielt vanskelig, da forfatterskab og datering af Historia Augusta er omstridt; værket regnes nu for at være en sen 4. århundredes litterær forfalskning med én forfatter, men foregivende at være skrevet af seks under Diocletian og Constantin (se R. Syme, Emperors and Biography, 1971). Uanset den specifikke historiske kildeværdi af de her nævnte passager bevidner de dog eksistensen af fænomenet som sådan.

32. Personlig affektion kunne fremkalde samme reaktionsmønster som social underlegenhed: gravindskrifter var ofte dediceret til afdødes Genius af dennes nærmeste familie, skønt dedikationer til en mands Genius i alle andre sammenhænge var et slavefænomen. Det samme gælder dedikationer for en privatpersons salus, der næsten altid er opsat enten af slaver eller af personens nærmeste familie. De to parter var i disse tilfælde af social jævnbyrdighed (eller »omvendt « underlegenhed, f.eks. en faders dedikation til sin afdøde søns Genius), normalt nært blodsbeslægtede - især herved afviger Marcus' æresbevisning - hvorfor social ydmygelse ikke var relevant. Jf. Sueton, C. Caligula 7: Livias dedikation af et billede af sit oldebarn i templet for den kapitolinske Venus.

33. Se note 4.

34. Der er intet belæg for portrætter af Divi, der kan modstilles Frontos ovenfor citerede passage.

35. Horats, Carmina 4,5: »Hinc ad vina redit laetus et alteris / te mensis adhibet deum. / Te multa prece, te prosequitur mero / defuso pateris et laribus tuum / miscet numen uti Graecia Castoris / et magni memor Herculis«. 


\section{Kejserkult i den romerske husstand}

36. Ovid, Fasti $2,633 \mathrm{ff}$; den kulthandlingen ledsagende formular har her følgende ordlyd: »bene vos bene te, patriae pater, optime Caesar«. Her næunes ceremonien netop for Caristia (22. februar), en fest for husguderne.

37. Blot på grund af parfumens kostbarhed - plantens brug var langtfra begrænset til religiøse ceremonier ( $R E$ s.v. Safran).

38. $\gg$ Rati ergo sacrum esse fericulum tam religioso apparatu perfusum, consurreximus altius et $»$ Augusto patri patriae feliciter $\ll$ diximus .

39. For den regerende kejser (Nero) nævnes overhovedet ikke, bortset fra her, i de bevarede dele af Satyricon. For varkets datering, se J. Sullivans introduktion med litteraturhenvisninger til hans oversættelse af Petronius i Penguin Classics.

40. Se Taylor 1931, $151 \mathrm{ff} ., 181 \mathrm{ff} ., 251,260,264$.

41. H. Kunckel, „Der römische Genius«, Mitteilungen des Deutschen Archäologischen Instituts, Römische Abteilung 20. Ergänzungsheft, 1974, 22, forsøger dog en argumentation: »Ist auch der Genius nicht ausdrücklich genannt [sc. hos Dio 51, 19,7], so muss man bei der betonten zurückhaltung des Augustus persönlichen Ehrungen gegenüber doch annehmen, dass es sich nur um den Genius Augusti handeln kann, nicht um Augustus selbst «. Men at direkte guddommelig kult skulle være mere anstødelig end Genius-kult, hviler på en kristen tankegang, der ikke a priori kan overføres på antikken.

42. Taylor $1931,217 \mathrm{ff}$.

43. Boyce 1937, nr. 466 med litteraturhenvisninger.

44. Som jeg kunne konstatere under mit besøg i Pompeii i juni 1988.

45. Mạu, Mitteilungen des Deutschen Archäologischen Instituts, Römische Abteilung V, 1890 , p. 244; Pompeji in Leben und Kunst, 1900, 253; heller ikke af denne graffito kunne jeg konstatere spor ved mit besøg.

46. Genius er i alle de pompejanske larariemalerier afbildet med togaen trukket op over hovedet, samt bærende enten overflødighedshorn eller, sjældnere, røgelsesskrin.

47. Hvis det er rigtigt, at præsten i vestvæggens offerscene ikke var capite velato (som romersk offerskik foreskrev), fulgtes i denne kult græsk ritus, hvad der kunne tyde på, at præsten (husets ejer) var en frigiven eller slave og således netop tilhørte den statusgruppe, der dyrkede kejserens Genius og officierede i Compitalkulten. For vidnesbyrd om Compitalkulten i Pompeii, se V. Spinazzola, Pompeii alla luce degli scavi nuovi di Via dell'Abbondanza, 1953, $169 \mathrm{ff}$.

48. Eksistensen af et senatsdekret i denne forbindelse er ikke overleveret, men forekommer naturlig, for compital-kollegierne blev i 1. århundrede f.v.t. netop undertrykt ved senatsdekret (RE s.v. Collegium, sp. 406 ff.), og genoprettelsen og reorganiseringen kan da logisk også kun være gennemført ved senatsdekret; jf. også dekretet om libationen (Cassius Dio 51, 19, 7).

49. Statuetter af Larerne, eller andre guder, kunne naturligvis have stået i kultnichen men det ændrer ikke ved det enestående i, at de, eller husherrens Genius, ikke er malet i forbindelse med offerscenen.

50. Den afbildede libation var således for-ceremoni til slagtningen, som normalt i de pompejanske larariemaleriers kultscener (Boyce 1937, passim; bemærk specielt Orr 1978, fig. 7, hvor grisen (til larerne) bæres til altret, netop som husherrens Genius udhalder libationen).

51. Ifølge Mau et hospitium, i modsætning til Sogliano, NSc 1891, 260. Huset var ved en gennemgang forbundet med nabohuset (IX, IX, 12) (Boyce 1937, 93 note 1); for nabohusets sacellum med larariemaleri, ligeledes vanskeligt tolkeligt, og løsfund i tilknytning hertil, se Boyce 1937, nr. 464. 


\section{Ittai Gradel}

\section{Summary}

"Emperor Worship in the Roman Household". - A recurrent statement in scholarship on the Roman imperial cult has been that the phenomenon was but a political expression of loyalty towards the emperor, involving little struly religious" sentiment for the worshippers. According to this argument, the cult was almost exclusively a public phenomenon. Private emperor worship has received surprisingly little attention from scholarship, but even in the unequivocally private sphere of the Roman household (in Italy), the cult of the living emperor seems to have been widespread during early imperial times. Although the difficult nature of the source material for private emperor worship calls for caution, this conclusion forms a basis for rejecting the traditional interpretation of the imperial cult as reductionist and christianizing.

\section{Ittai Gradel}

Stud. mag.

Kollegium 1, vær. 4

Universitetsparken

8000 Århus C 